\title{
POOPERACINĖS SEROMOS IR ŽAIZDŲ PRIEŽIŪRA PO KRŪTIES OPERACIJU
}

\author{
Jurgita Bičkaitienė ${ }^{1}$, Agnė Čižauskaitė ${ }^{2,3}$, Vitalina Narmontienė ${ }^{2}$ Dainius Šimčikas ${ }^{3,4}$, \\ Alvydas Česas ${ }^{2}$ \\ ${ }^{I}$ Klaipèdos universitetinès ligoninès Ambulatorinis konsultacinis skyrius, \\ Hospitalizacijos departamentas, ${ }^{2}$ Klaipeddos universitetinès ligonines \\ Onkologijos chemoterapijos klinika, ${ }^{3}$ Klaipédos universiteto Sveikatos mokslu fakulteto \\ Slaugos katedra, ${ }^{4}$ Klaipèdos universitetinès ligoninès Pilvo ir endokrininès chirurgijos klinika
}

Raktažodžiai: krūtų chirurgija, pooperacinè komplikacija, seroma, krūtų priežiūros slaugytoja.

\section{Santrauka \\ Krūties vėžys - dažniausia onkologinè moterų liga Lietuvoje ir pasaulyje. Kasmet atliekama daugybė krūtų operacijų, kurios pasižymi specifiškomis kom- plikacijomis. Dažniausia iš jų seroma, pasitaikanti $3-85 \%$ atvejų. Nekomplikuotų krūties ir pažasties sričių seromų evakavimo procedūros kai kurių šalių ligoninėse patikètos krūtų priežiūros slaugytojoms.}

\section{Ivadas}

Higienos instituto Sveikatos informacijos centro duomenimis, 2016 m. Lietuvoje užregistruoti 12499 asmenys, sergantys onkologinėmis krūtų ligomis, iš jų 2386 naujai, pirmą kartą nustatyti atvejai. Priklausomai nuo ligos išplitimo, daugumai pacientų taikomas operacinis gydymas - mastektomija (krūties pašalinimas), arba krūtị tausojati operacija. 2015 m. ir 2016 m. Lietuvoje buvo atliktos atitinkamai 736 ir 684 poodinès ir paprastos mastektomijos operacijos bei 2201 ir 2184 krūties pažeidimo ekscizijos [1].

Nors krūtų operacijos pasižymi žemu komplikacijų dažniu, tai - gana specifinè chirurgijos sritis, turinti daug ypatumų. Pooperaciniu periodu pacientes reikia stebèti dèl galimų komplikacijų ir pašalinių reiškinių. Seromų formavimasis - problema, ị kurios sprendimą ịtraukiama pacienté, jos artimieji, slaugytojai, gydytojai chirurgai ir kitų specialybių gydytojai.

Šio straipsnio tikslas - aptarti pooperacines krūtų chirurginio gydymo komplikacijas, įvertinti pooperacinès seromos dažni bei jos atsiradimą sąlygojančius veiksnius. Taipogi apsvarstyti galimybę, jog seromos bei kitų mažųjų pooperacinių komplikacijų valdymą savarankiškai spręstų slaugytoja, suteikiant naujas kompetencijas bei nurodant šio proceso suderinamumą su šiuo metu vykdoma Nacionaline slaugos politika.

\section{Medžiagos ir metodai}

Atlikta mokslinès literatūros, publikuotos 2006 - 2017 m., apžvalga ir sisteminè analizè. Anglų kalba publikuotų mokslinès literatūros šaltinių ieškota duomenų bazėse: $P u$ bMed, Medline. Naudoti raktiniai žodžiai: breast cancer, postoperative complications after breast surgery, seroma, breast care nurse. Kadangi vienas iš straipsnio tikslų buvo atkreipti dèmesị i galimybę pakeisti mažųų pooperacinių komplikacijų priežiūros praktiką, išnagrinèti Lietuvos Respublikos sveikatos apsaugos ministro ịsakymai.

\section{Diskusija}

Po krūtų operacijų gali pasireikšti bendrosios, specifinès ir retos pooperacinè komplikacijos.

Remiantis literatūros duomenimis, bendrosioms pooperacinėms komplikacijoms priskiriama: pooperacinių žaizdų gijimo sunkumai (infekcija, pooperacinis žaizdos išsiskyrimas, hipertrofinis (dar vadinamas keloidinis) randas ir kt.), seroma, hematoma bei venine tromboembolija [2].

Žaizdos infekcijos paplitimas svyruoja 1 - 29\%, ją dažniausiai sukelia stafilokokų kilmès mikroorganizmai. Nustatyti veiksniai, didinantys žaizdos infekcijos riziką, tai - nutukimas, vyresnis ligonès amžius, cukrinis diabetas bei žalingi ịpročiai - rūkymas žaizdos infekcijos riziką padidina 4 kartus. Taivano mokslininkų grupé, tyrusi pooperacinès žaizdos serozinio skysčio kiekio įtaką infekcijai susidaryti nustatè, jog per parą nupunktuojamas ar nudrenuojamas skysčio kiekis infekcijos rizikos neveikia. Ilgalaikis audinių dreno naudojimas kiekvieną savaitę infekcijos riziką padidina $76,2 \%$. Infekcijos rizikai taip pat neturi ịtakos operacijos ap- 


\section{2}

imtis - ar tai būtų mastektomija, ar krūtị tausojanti operacija.

Infekcijos dažnį $>40 \%$ mažina priešoperacinè antibiotikų profilaktika, kuri atliekama 30 minučių iki operacijos pradžios. Dažniausiai naudojami cefalosporinų kartos antibiotikai. Nežymus minkštujų audinių uždegimas (celiulitas) gali būti gydomas peroraliniais antibiotikais. Esant abscesui (dažniausiai - supūliavus seromai), reikia evakuoti žaizdoje esančius pūlius. Atliekama aspiracinè punkcija, jei ji neefektyvi - atliekamas absceso ertmès drenavimas bei plovimas. Kraštutiniu atveju atliekamas žaizdos atvėrimas, skiriami antibiotikai. Nesant efekto skiriant peroralinius antibiotikus, jie skiriami intraveniškai ir ligonè hospitalizuojama.

Rando formavimuisi įtakos turi chirurginè technika intraodine siūlè, monofilamentinis siūlas, pjaunanti atrauminè adata. Žaizdos tempimą mažina Steri-Strip pleistrai. Po operacijos pacientėms rekomenduojama dèvèti palaikomają liemenèlę. Keloidiniams randams formuotis turi įtakos genetinis polinkis. Kaip formuosis randas, priklauso ir nuo jo lokalizacijos. Blogiausiai formuojasi randai, esantys krūtinkaulio srityje. Išoriniai randų kremai suminkština randą. Dèl silikoninių tvarsčių ir masažo, randas yra spaudžiamas, jis plokštėja. Pacientė gali pati naudoti randą spaudžiančias priemones, kasdien randą lengvai masažuoti. Randams mažinti gali būti atliekamos steroidinių vaistų injekcijos, intensyvi pulsinè šviesos terapija, mikrodermoabrazija, radioterapija ir kt. [3].

Seroma - tai poodinio serozinio skysčio susikaupimas negyvoje ertmeje po krūties, jos dalies ar pažasties limfmazgiu pašalinimo pažasties duobeje. Seromos formavimosi dažnis pooperaciniu periodu po mastektomijos ir pažasties limfmazgių pašalinimo svyruoja $3-85 \%$. Seromos susiformavimas po krūties operacijos, autoriu teigimu, yra vertinamas labiau kaip pašalinis operacijos efektas nei komplikacija. Tai nèra grèsminga gyvybei būklè, tačiau kelia didelị nerimą pacientei. Dèl užsitęsusio serozinio skysčio kaupimosi žaizdoje atidedamas adjuvantinis (pooperacinis) spindulinis gydymas, padideja infekcijos rizika. Dažniausia pooperacinio absceso krūtyje priežastis - laiku neevakuota pooperacinè seroma. Seroma, kuri susiformuoja po audinių drenų pašalinimo, gydoma kartotinomis aspiracinėmis punkcijomis (10 - 80\%). Aspiracinę punkciją pacientės gerai toleruoja dèl odos nejautros, kuri atsiranda dẻl smulkių odą ịnervuojančių nervų pažeidimo po odos - poodžio atidalinimo operacijos metu [4]. Atlikta įvairių studijų, siekiant išsiaiškinti, kokie veiksniai skatina seromos atsiradimą. Patikimų, besiremiančių viena randomizuota studija, tyrimų duomenimis, seromos atsiradimo riziką didina didelis kūno svoris, išplèstinè radikali mastektomija, didelis serozinio skysčio kiekis per drenus pirmas 3 pooperacines paras. Po atlikto pažasties limfmazgių pašalinimo (vad. limfodisekcijos) seromos tikimybė statis- tiškai didesnẻ nei pašalinus tik sarginị krūties limfmazgị. Remiantis aprašomosiomis studijomis, nustatyta, jog seromu atsiradimą taip pat didina diagonalinis pjūvis (lyginant su vertikaliu), arterinè hipertenzija, daug skylučių turintys drenai (lyginant su daugiakanaliais drenais), nedrenavimas, ilgas operacijos laikas, ankstyvas dreno pašalinimas, elektrokauterio naudojimas audiniams operacijos metu atskirti [5]. Seromų atsiradimo riziką mažina mastektomija, kartu atliekant vienmomentę krūties rekonstrukciją, audinių fiksavimas prie krūtinès ląstos sienos, ultragarsinès žirklès [6]. Nustatyta, jog nei tumoro dydis, nei išplitimas, nei rūšis, spindulinė terapija, drenų skaičius, drenavimo slègio stiprumas, cukrinis diabetas, krūties dydis, rūkymas, peties judesiai statistiškai reikšmingos įtakos seromai susiformuoti neturi [5].

Dèl trumpo pacienčių po krūties operacijų hospitalizacijos laiko, ị namus jos išvyksta pooperacinei žaizdai dar esant proliferacinejje, ar net uždegimo stadijoje. Drenas dažniausiai būna ištraukiamas antrą trečią pooperacinę parą arba, kai per parą dreno rezervuare susirenka mažiau nei $30 \mathrm{ml}$ sekreto [7]. Pacientès, kurioms žaizdos eksudato išsiskyrimas per drenus nemažèja, ị namus išrašomos su jais. Pacientès ir jų artimieji turi gauti reikiamą informaciją, kaip prižiūrèti drenus bei pooperacines žaizdas.

Kaip nurodoma Jungtinės Karalystės Karališkojo sveikatos apsaugos koledžo paruoštoje rekomendacijoje, namuose aktyvaus drenavimo sistemą prižiūrintys asmenys turi būti išmokyti:

- saugoti, kad drenas nebūtų tempiamas, nes tai gali sukelti diskomfortą ir padidinti dreno savaiminio išsitraukimo riziką;

- patikrinti, ar dreno skysčio surinkimo rezervuaras yra suspaustas, nes tik jame susidaręs vakuumas traukia skysti iš žaizdos;

- stebèti rezervuare esantị skystị - jis turi būti skaidrus, o spalva gali svyruoti nuo tamsiai rausvos iki šviesiai gelsvos;

- kasdien stebėti tvarsčius aplink dreno ịkišimo sriti galima pastebèti pro šalį tekantị skystị;

- kasdieną tuo pačiu metu matuoti skysčio kiekį rezervuare ir dokumentuoti išrašant iš stacionaro slaugytojos duotoje specialioje medicinineje formoje.

Informuoti savo gydytoją ar krūtų priežiūros slaugytoją, jei:

- skystis teka aplink dreną;

- rezervuaras nebesusispaudžia - pažeistas, nesusiformuoja vakuumas;

- rezervuare esantis skystis staiga pakeité spalvą (tapo drumstas, raudonas, balkšvas, pilkšvas ir kt.);

- atsirado stiprus skausmingumas pooperacinès žaizdos srityje, stebimas odos paraudimas, patinimas ar sukietejimas žaizdos srityje ar aplink dreną; 
- drenas iškrito [8].

$2008 \mathrm{~m}$. Lietuvos sveikatos mokslų universiteto studentès atliko tyrimą, kaip suteikiama informacija pacientems po krūties operacijų. Analizuota galimų komplikacijų tikimybė po krūties věžio operacijų, šios informacijos gavimo šaltiniai. Nurodytas slaugytojų poreikis mokyti pacientes, kaip galima išvengti galimų komplikacijų po krūties věžio operacijos. Ištyrus pacienčiu atsakymus į anketos klausimus, nustatyta, jog daugiausia informacijos apie komplikacijas po krūties věžio operacijos ir jų prevenciją (33,3\%) jos gavo tik 2 - 4 parą po operacijos. $68,4 \%$ pacienčių teigè, jog informaciją jos gavo iš kitų ligonių, o ne iš kvalifikuotų specialistų [9].

Hematomos dažnis po krūtų chirurginio gydymo siekia 2 -10\%. Mažo kraujo kiekio hematoma - ekchimozè - kraujo išsiliejimas odoje ir poodiniuose audiniuose, kurie sugeria nedidelị laisvo kraujo kiekị. Gydymui pakanka kompresinio bintavimo, vietiškai taikomo šalčio. Didelio kiekio hematomos pasireiškia skausmingumu dèl staigaus uždaros ertmès tempimo. Didelès hematomos turi būti evakuotos - pro drenus, atvertą operacini pjūvị ar operacinèje. Kraujo perpylimas net ir esant didelèms hematomoms po krūties operacijų dažniausiai nėra reikalingas. Hematomos profilaktika: ortopedinès liemenèlès didelių krūtų pooperaciniam palaikymui - visą parą keletą dienų po operacijos. Vengti aspirino turinčių produktų, nesteroidinių vaistų nuo uždegimo (pvz. ibuprofeno), taip pat žolinių preparatų su imbieru, ginkmedžiu ir česnaku, kurie pasižymi kraujavimo riziką didinančiu poveikiu (1-2 savaitès iki operacijos) [2]. Atsiradus ị hematomą panašiam bėrimui, praejus keletui savaičių po operacijos, reikia kuo skubiau informuoti gydytoją onkologą dèl galimo onkologinès ligos atkryčio ar progresavimo (1 paveikslas).

Veninè tromboembolija yra reta pooperacinè komplikacija ir išsivysto $0,16 \%$ atvejų po chirurginių krūties operacijų. Sisteminè veninès tromboembolijos profilaktika ịprastų krūtų operacijų metu nèra tikslinga, ypač atsižvelgiant ị tai, jog pooperacinės hematomos riziką gali padidinti iki trijų kartų. Veninès tromboembolijos profilaktika taikoma aukštos rizikos pacientėms, kuomet yra diagnozuotas prieširdžių virpèjimas, dirbtiniai širdies vožtuvai, anamnezèje buvę smegenų kraujotakos sutrikimai ar tromboembolinès komplikacijos. Iprastų operacijų metu pakanka kojų kompresijos [2].

Specifinès komplikacijos po krūtų operacijų:

- dalinis/visiškas spenelio - areolès komplekso netekimas ar jo nekrozé;

- dalinis/visiškas audinių lopo netekimas;

- atoki krūtinès fibrozė (surandejjimas), limfedema, celiulitas (poodinio audinio uždegimas, kurio paplitimas siekia $5 \%$, gali pasireikšti nuo kelių mėnesių iki keleto metų po krūties operacijos ar spindulinio gydymo; atsiradus celiulitui, tikslingas kartotinis vaizdinis krūties ištyrimas ir nuolatinè gydytojo onkologo priežiūra siekiant ekskliuduoti ligos atsinaujinimo galimybę, nes uždegiminis krūties věžio recidyvas gali atrodyti kaip celiulitas);

- su krūties implantu susijusios komplikacijos: implanto pragula, kapsulès kontraktūra (aplink implantą susiformuoja kieta jungiamojo audinio kapsule, kuri deformuoja jos viduje esantị implantą), implanto protruzija, infekcija, kuri gali komplikuotis implanto netekimu ir kt. [2].

Pacientèms, kurioms įdèti implantai, gali pasireikšti reto tipo ne Hodžkino T limfocitų limfoma (BIA-ALCL - su implantais susijusi anaplastinè didelių ląstelių limfoma). Iki 2017-02-01 JAV užregistruoti 359 šios ligos atvejai. Pagrindinis simptomas - vèlyvai pasireiškianti, besitęsianti aplink implantą ultragarsu stebima seroma. İtarimus patvirtina teigiamas CD30 molekulių tyrimas seromos skystyje. Radikaliai pašalinus implantą ir jo kapsulę, daugumos pacienčių prognozè labai gera [10].

Literatūroje taip pat aprašomos retos pooperacinès komplikacijos. Viena jų - pneumotoraksas, kuriuo gali komplikuotis navikų priešoperacinis žymejjimas viela. Jis taip pat gali įvykti šalinant auglius, peraugusius krūtinès ląstą. Su paciento rankos pozicionavimu operacijos metu susijusi komplikacija - žasto srities nervinio rezginio pažeidimas. Jis gręsia tuomet, kai ranka operacijos metu atvedama daugiau nei 90 laipsnių. Mondoro liga - torakoepigastrinès venos trombozè [2].

Kai kuriose šalyse mažąsias pooperacines komplikacijas igaliotos spręsti slaugytojos. Dar $1996 \mathrm{~m}$. Izraelyje buvo isteigtas krūties priežiūros slaugytojos etatas, iki šiol turintis stiprią mokymų bazę [11].

Seromos punktavimo praktika Suomijoje. 2017-09-15 Klaipėdoje vykusioje tarptautinèje krūties vėžiui skirtoje konferencijoje, organizuotoje Lietuvos onkologų chemoterapeutų draugijos bei Klaipėdos universitetinès ligoninès,

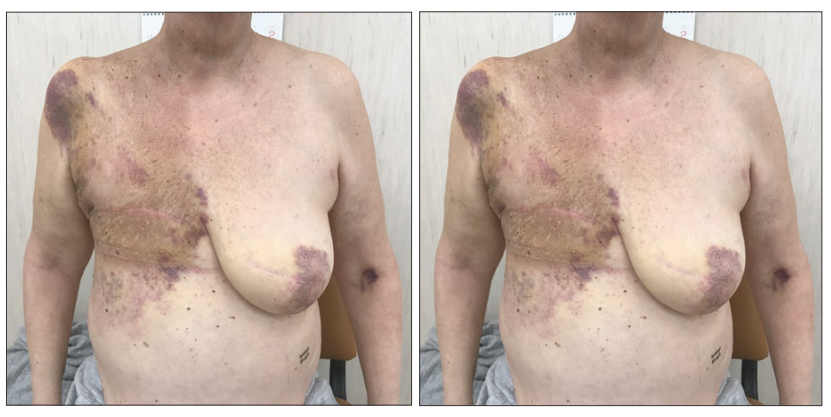

1 paveikslas. Ligonei, kuriai atliktas dešinès krūties pašalinimas dèl krūties véžio, 3 savaitès po operacijos atsirado ị poodinę hematomą panašus bėrimas. Atlikus pažeistos odos biopsiją buvo nustatytas vèžio plitimas odoje 
popietinei paralelinei slaugos sesijai pirmininkavusi viešnia iš Suomijos, krūtų priežiūros slaugytoja Ulla Drake pasidalijo savo patirtimi, konsultuojant bei slaugant pacientes, kurioms diagnozuota onkologinè krūties liga. Pasak pranešèjos, Helsinkio universitetinejje ligoninejje dirba trys krūtų priežiūros slaugytojos. Pacientai gauna slaugytojos konsultaciją, kuri trunka nuo 15 min. iki 1 val. Konsultacijos metu slaugytojos atsako ị dèl diagnozuotos onkologinès krūties ligos pacientėms kilusius klausimus, susijusius su gydymo planu, galimomis komplikacijomis, slauga, tolimesniais tyrimais, gyvenimo kokybe. Pacientès sužino, kur kreiptis psichologinès, medicininès ar socialinès pagalbos. Konsultacijoje skatinami dalyvauti ir pacientès artimieji. Pasak viešnios iš Suomijos, slaugytojos kasdien konsultuoja, derina gydymo planus, nustatytu laiku atsakinejja telefonu i pacientams iškilusius klausimus, pasitelkdamos gydytojus rezidentus punktuoja po krūties operacijos susidariusias seromas.

Jungtinès Karalystės patirtis. Jungtinèje Karalystejje už poperacinès krūtų seromos punktavimą taip pat atsakingos specialiai apmokytos slaugytojos. Melissa Warren (antrinès krūties véžio priežiūros klinikinès slaugos specialistè) 2008 m. British Journal of Nursing išspausdintame straipsnyje pristate slaugytojoms skirtą seromos aspiravimo algoritmą. Straipsnyje apibūdinta situacija, paskatinusi seromos aspiravimą bei žaizdos vertinimo funkcijas patikèti krūties věžio slaugytojai. Melissa Warren analizavo padètį krūtų chirurgijos skyriuose bei paskelbè įžvalgas apie veiksnius, galinčius paveikti reformos vykdymą. İvertinusi aplinką, kurioje turi ivvykti pakitimai, kaip teigiamas reformai priimti aplinkybes ji ịvardijo visų krūties multidisciplininès komandos narių entuziazmą, motyvaciją ir ịsipareigojimą; gydytojo norą atsisakyti seromos aspiravimo vaidmens; krūties ligų specialisto norą atlikti oficialų mokymą apie pacientų priežiūrą ir gydymą su seromos aspiravimu; konsultanto chirurgo norą parengti mokymo paketą ir prižiūrèti krūties priežiūros slaugytoją, vertinant seromų formavimąsi ir serumo aspiraciją; tinkamą klinikos erdvę ir laiko tarpą, skirtą slaugytojui pradeti vadovauti seromų aspiracijos tarnybai; lengvai pasiekiamą chirurginès komandos pagalbą; Vyriausybès vykdomą „Vèžio reformos strategiją“.

London Cancer Alliance seromos punktavimo gide krūtų priežiūros slaugytojui nurodoma konkreti instrukcija, kaip punktuoti seromą, kokie pacientų pasirinkimo procedūrai kriterijai. Pasak šios institucijos rekomendacijų, slaugytojas neturètų punktuoti pooperacinių seromų, kai:

pacientė nesutinka su paskirta gydymo procedūra; - pacientè turi krūtų implantus - dèl rizikos juos pažeisti;

- operacija buvo anatomiškai sudètinga;

- patinimas yra nežymus ir nesukelia diskomforto; - pacientei atliekama chemoterapija arba radioterapija; patinimai pulsuojantys - galintys turèti kraujagyslinių komponentu [12].

Šveicarijoje profesionalios krūtu priežiūros slaugytojos klinikinè veikla - tik vienas darbo aspektų. Labiau akcentuojamas jos visuomeninis, mokytojo, konsultanto, tyrimu autoriaus, bendradarbiavimo su kitais sveikatos priežiūros specialistais, kitomis sveikatos priežiūros institucijomis bei ivvairiomis pacientų organizacijomis vaidmuo [13].

Pagal Lietuvoje šiuo metu igyvendinamą Nacionalinę slaugos politiką 2016 - 2025 m., 2017 m. magistro kvalifikacinis laipsnis suteiktas pirmosioms išplèstinès praktikos studijas baigusioms slaugytojoms, pasirinkusioms vieną iš trijų specializacijų: pirminę sveikatos priežiūrą, skubiają medicininę pagalbą ar anesteziją ir intensyvią terapiją. Besiverčiančios išplèstine praktika slaugytojos turètų perimti dali gydytojų funkcijų. Joms suteiktos naujos kompetencijos, igalinančios gautas žinias realizuoti praktikoje $[14,15]$.

Ar krūtų priežiūra galètų tapti dar viena išplèstinès praktikos slaugos specializacija? Šiame straipsnyje minètas seromos punktavimas bei pooperacinė pacientų priežiūra - tik maža dalis darbo, kurị krūtų priežiūros slaugytoja galètų nuveikti. Plačiau panagrinèti būsimos krūtų priežiūros slaugytojos etato poreikị bei galimas teises, pareigas, kompetencijas ir atsakomybę, reikalinga atskira studija.

\section{Išvados}

Pooperacinis krūtų chirurgijos periodas pasižymi specifinemis, nors ir nedažnomis komplikacijomis. Pooperaciné seroma - labiau šalutinis operacijos poveikis, nei komplikacija. Tačiau tinkamai negydomos seromos gali komplikuotis. Pacientų ir jų artimujų mokymas gali padèti išvengti pooperacinių komplikacijų ar laiku jas atpažinti ir gauti profesionalią pagalbą. Šalyse, kur seromos punktavimą atlieka slaugytojai, vykdomi specialūs mokymai, suteikiami konkretūs ịgaliojimai bei kuriami procedūrų valdymo algoritmai. Tikslingas tolimesnis tyrimas, ar Lietuvoje reikalinga krūtų priežiūros slaugytojos specializacija, kurią igijusi slaugytoja turètu teisę ir kompetenciją savarankiškai spręsti su mažosiomis pooperacinèmis komplikacijomis susijusius uždavinius.

\section{Literatūra}

1. Higienos instituto Sveikatos informacijos centras. Lietuvos gyventojų sveikata ir sveikatos priežiūros įstaigų veikla 2016 m. 2017;94:110.

2. Vitug AF. et al. Complications in breast surgery. Surg Clin North Am 2007;87(2):431-51.

https://doi.org/10.1016/j.suc.2007.01.005

3. Chen CF. et al. Risk of infection is associated more with drain duration than daily drainage volume in prosthesis-based breast reconstruction: A cohort study. Medicine (Baltimore). 
2016;95(49):e5605.

https://doi.org/10.1097/MD.0000000000005605

4. Srivastava V. et al. Seroma formation after breast cancer surgery: what we have learned in the last two decades. Journal of Breast Cancer 2012 December; 15(4): 373-380.

https://doi.org/10.4048/jbc.2012.15.4.373

5. Kuroi K. et al. Evidence-based risk factors for seroma formation in brest surgery. Jpn J Clin Oncol 2006;36(4)197-206 https://doi.org/10.1093/jjco/hyl019

6. Stoyanov G. et al. Drainage after Modified radical mastectomy - a methodological mini-review. Cureus 2017;9(7):e1454. https://doi.org/10.7759/cureus.1454

7. Voineskos SH. et al. Breast reconstruction following concervative mastectomies: predictors of complications and outcomes. Gland Surg 2015; 4(6):484-96.

8. Imperial College Healthcare. Going home with a wound drain after breast surgery. https://www.imperial.nhs.uk/serch/ keywords

9. Lekauskaitė A. ir kt. Informacijos suteikimo svarba komplikacijų prevencijoje po krūties vėžio operacijos. Sveikatos mokslai, 2008;6(60):2038-45.

10. Hwang MJ. et al. Breast implant-associated anaplastic large cell lymphoma: a case report and literature review. Aesthetic Plast Surg. 2015;39(3):391-5. https://doi.org/10.1007/s00266-015-0463-2

11. Kadmon I. et al. Israeli breast care nurses as a learning organization. Asia Pac J Oncol Nurs 2015;2(1):3-7. https://doi.org/10.4103/2347-5625.146227

12. Warren M. Collaboration in developing a protocol for nurse-led seroma aspiration. British Journal of Nursing 2008;17(15):956-60. https://doi.org/10.12968/bjon.2008.17.15.30697
13. London Cancer Alliance. Seroma Aspiration Guidance. http://rmpartners.cancervanguard.nhs.uk/wp-content/ uploads/2017/03/1ca-seroma-guidance-jan-2016-v10.pdf

14. Lietuvos Respublikos sveikatos apsaugos ministro įsakymas dèl Nacionalinès slaugos politikos 2016-2025 metų gairių patvirtinimo. $2016 \mathrm{~m}$. vasario $10 \mathrm{~d}$. Nr. V-222, Vilnius.

15. Lietuvos Respublikos sveikatos apsaugos ministro įsakymas dèl Lietuvos medicinos normos MN 160:2017 "Išplèstinès praktikos slaugytojas" patvirtinimo. $2017 \mathrm{~m}$. liepos $7 \mathrm{~d}$. Nr. V-852, Vilnius.

\section{POSTOPERATIVE SEROMA AND WOUND CARE AFTER BREAST SURGERY}

\section{J. Bičkaitienė, A. Čižauskaitè, V. Narmontienė, D. Šimčikas,}

\section{A. Česas}

Key words: breast surgery, postoperative complication, seroma, breast care nurse.

Summary

Breast cancer is the most common female oncologic disease in Lithuania and worldwide. Plenty of breast surgeries are performed every year and plenty of specific postoperative complications are to deal with. The most common complicaton after breast surgery is seroma occuring $3-85 \%$ of cases. In some countries the treatment of not complicated breast and axillar seromas belongs to breast care nurses.

Correspondence to: agne.cizauskaite@gmail.com

Gauta 2017-11-06 